\title{
PEREMPUAN DALAM THARIQAH (STUDI TERHADAP PERAN PEREMPUAN DALAM THARIQAH TIJANIYAH BANGKA)
}

\author{
Ichsan Habibi \\ IAIN Syaikh Abdurrahman Siddik Bangka Belitung, Indonesia \\ ichsanhabibi@gmail.com
}

\begin{abstract}
Abstrak: Perempuan merupakan subjek yang memiliki pengaruh dalam senarai lintasan sejarah kehidupan manusia, termasuk dalam sejarah Islam. Tulisan ini bertujuan mengeksplorasi bagaimana dinamika "wajah" perempuan dalam thariqah Tijaniyah di Bangka. Penelitian ini merupakan penelitian kualitatif yang melibatkan wawancara mendalam sebagai penggalian data primer, kemudian didukung dengan kajian literatur mengenai keterlibatan perempuan dalam thariqah. Temuan penelitian menunjukkan bahwa: 1) Sosok tokoh perempuan dalam thariqah Tijaniyah yakni seorang perempuan yang mengamalkan thariqah syar'iyah yang memiliki lahir dan batin yang baik; 2) Tokoh perempuan dalam tariqah Tijaniyah berperan sebagai juru dakwah, tauladan yang baik, pembimbing, pemecah masalah keseharian para pengikut thariqah kaum perempuan dan perpanjangan lidah dari mukadam ikhwan yang berijazah; 3) kendala yang dihadapi adanya pertentangan pemahaman dan belum yakinnya masyarakat dengan tariqat Tijaniyah; 4) problem yang terjadi dalam thariqah tidak perlu ditakuti karena itu tidak perlu dirisaukan kaena itu bukanlah suatau ancaman; 5) dalam thariqah Tijaniyah di Bangka tidak ada kaderisasi secara khusus untuk membentuk muqaddam dari kalangan perempuan, namun perempuan yang terpilih itu murni langsung petunjuk dari sang mukaddam di atasnya.
\end{abstract}

Kata Kunci: Peran Perempuan, Thariqah Tijaniyah, Bangka 
Perempuan dalam Thariqah (Studi Terhadap Peran Perempuan Dalam Thariqah Tijaniyah Bangka)

\section{A. Pendahuluan}

Pendidikan Sejak masa Nabi Muhammad saw, banyak tokoh perempuan Islam yang berperan dalam kehidupan masyarakat dan agama serta memiliki kesucian jiwa. Hal ini dimungkinkan karena dalam Islam tidak ada perbedaan perlakuan, tempat, dan kesempatan antara laki-laki dan perempuan untuk mendekatkan diri kepada Allah Swt. Artinya, secara spiritual, peluang untuk mencapai ma'rifatullah terbuka untuk keduanya.Sebagaimana firman Allah:

Sesungguhnya laki-laki dan perempuan yang muslim, laki-laki dan perempuan yang mukmin, laki-laki dan perempuan yang tetap dalam ketaatannya, laki-laki dan perempuan yang benar, laki-laki dan perempuan yang sabar, laki-laki dan perempuan yang khusyuk, laki-laki dan perempuan yang bersedekah, laki-laki dan perempuan yang berpuasa, lakilaki dan perempuan yang memelihara kehormatannya, laki-laki dan perempuan yang banyak menyebut (nama) Allah, Allah telah menyediakan untuk mereka ampunan dan pahala yang besar.

Dan tidaklah patut bagi laki-laki yang mukmin dan tidak (pula) bagi perempuan yang mukmin, apabila Allah dan rasul-Nya telah menetapkan suatu ketetapan, akan ada bagi mereka pilihan (yang lain) tentang urusan mereka, dan barangsiapa mendurhakai Allah dan rasul-Nya, maka sesungguhnya dia telah sesat, sesat yang nyata. (QS. Al-Ahzab/33: 35-36). ${ }^{1}$

Beberapa tokoh perempuan berikut banyak dikenal dalam sejarah Islam, mulai dari istri pertama Nabi saw, Siti Khadijah yang rela mengorbankan harta bendanya untuk perjuangan suaminya menyebarkan Islam. Begitupun putri beliau, Siti Fatimah (yang menjadi istri Ali bin Abi Thalib) sehingga dikenal dengan julukan Umm alMu'min. Ada juga Nafisah (buyut Hasan bin Ali bin Abi Thalib), atau Rabi'ah alAdawiyah (tokoh sufi perempuan yang terkenal dengan "filsafat cinta"-nya); dan masih banyak nama lainnya. Sayangnya, hanya sebagian kecil yang tercantum dalam catatan-catatan resmi sehingga sulit untuk diurai secara lebih mendalam mengenai peran mereka dalam sejarah Islam. ${ }^{2}$

Meskipun dalam beberapa biografi Muslim banyak disebutkan, namun jumlah tokoh perempuan Islam tersebut tidak diketahui secara pasti dan sangat beragam.

${ }^{1}$ Al-Qur'an dan Terjemahnya, (Jakarta: Departemen Agama-Kerajaan Saudi Arabia, 1990).

${ }^{2}$ Azyumardi Azra menyebut kondisi sejarah ulama perempuan seperti ini sebagai sejarah yang gelap sebab tidak banyak informasi yang bisa digali. Oleh karena itu penting untuk memberi perhatian khusus tentang kajian ulama perempuan. Lihat Sururin, "Perempuan dan Tarekat"dalam Tim, Islam dan Isu-isu Kontemporer, (Jakarta: Ditjen Bimmas Islam, 2010), hlm. 100. 
Berikut beberapa penulis yang menyebutkan nama-nama tokoh perempuan dalam koleksinya:

1. Ibn Sa'ad (168H/765M-230H/845M), seorang penulis biografi Muslim paling awal, dalam Kitab al-Thabaqat al-Kabir Jilid VIII, ${ }^{3}$ menuliskan 629 sahabat perempuan dari total 4.250 entri koleksinya.

2 Al-Khatib al-Baghdadi $(463 \mathrm{H} / 1070 \mathrm{M})$, menyebutkan 31 nama tokoh perempuan dari 7.800 entri yang disusunnya.

3. Ibn 'Asakir $(571 \mathrm{H} / 1176 \mathrm{M})$ menulis 200 nama tokoh perempuan dalam 13.500 entri koleksinya.

4. Fariduddin al-Attar $(628 \mathrm{H} / 1230 \mathrm{M})$, dalam karya popularnya Tadzkirah al-Auliya', menyebutkan satu nama terkenal, yakni Rabi’ah al-Adawiyah (w. 185H) dari 72 sufi terkenal.

5. Ibn Khalikan $(681 \mathrm{H} / 1282 \mathrm{M})$, menuliskan enam nama tokoh perempuan dalam 826 entri koleksinya.

6. Jami $(898 \mathrm{H} / 1492 \mathrm{M})$, memuat 35 nama tokoh perempuan dalam 564 entri yang disusunnya.

7. Al-Shakawi $(902 \mathrm{H} / 1497 \mathrm{M})$ menulis 1.075 entri perempuan dari 11.691 nama tokoh Muslim.

8. Al-Ghazzi $(1061 \mathrm{H} / 1651 \mathrm{M})$ memasukkan 12 nama tokoh perempuan dari 1.647 entri koleksi biografinya.

9. Abdurrahman bin Ali bin al-Jauzi $(597 \mathrm{H} / 1200 \mathrm{M})$, dalam biografinya menuliskan 240 nama tokoh perempuan atau hampir seperempat dari jumlah entrinya. ${ }^{4}$

Dalam bidang tasawuf, dari berbagai literatur yang ada, diketahui bahwa perempuan juga telah memainkan peran penting dalam sejarah pemikiran dan mistisisme. ${ }^{5}$ Namun dari sejumlah nama, terdapat satu nama yang dipandang sejajar

\footnotetext{
${ }^{3}$ Kitab ini telah diterjemahkan ke dalam bahasa Indonesia oleh Eva Y. Nukman dengan judul Purnama Madinah: 600 Shahabat Wanita Rasulullah SAW yang Menyemarakkan Kota Nabi, (Bandung: al-Bayan, 1997).

${ }^{4}$ Karya-karya biografi tersebut telah diteliti oleh Ruth Roded dan ditulis dalam Women in Islamic Biographical Collections from Ibn Sa'd to Who's Who, yang dalam edisi bahasa Indonesia berjudul Kembang Peradaban. Lihat Sururin, "Perempuan dan Tarekat"

5 Mistisisme dalam Islam merupakan kata lain dari tasawuf atau sufisme.Annemarie Schimmel dalam Dimensi Mistik dalam Islam, terj. Sapardi Djoko Damono, dkk., (Jakarta: Pustaka Firdaus, 2003), cet. ke-2, menyebutnya sebagai praktik mistik. Lihat juga Harun Nasution, Falsafat \& Mistisisme dalam Islam, (Jakarta: Bulan Bintang, 1990), cet. ke-3; Simuh, Tasawnf dan Perkembangannya di Indonesia, (Jakarta: Rajawali Press, 2002), cet.
} 
Perempuan dalam Thariqah (Studi Terhadap Peran Perempuan Dalam Thariqah Tijaniyah Bangka)

dengan guru sufi laki-laki, dialah Rabi'ah al-Adawiyah (95H/717M), guru sufi yang terkenal dengan gagasan spiritualnya, hubb al-ilabi. ${ }^{6}$ Menurut Ibn Khalikan, perempuan sufi yang lahir di Basrah sekitar tahun $95 \mathrm{H} / 717 \mathrm{M}$ ini diberi nama yang sederhana, Rabi'ah, karena ia merupakan anak keempat. Nama yang sederhana ini diberikan karena keluarganya berharap yang lahir adalah anak laki-laki.Pada masa itu, keberadaan anak laki-laki memiliki nilai tersendiri di dalam masyarakat, sebagai tumpuan keluarga, sementara ketiga anak sebelumnya adalah perempuan.

Meski demikian, setelah menjalani pasang-surutnya kehidupan, Rabi’ah alAdawiyah kemudian menjadi guru sufi dan memperkaya gagasan spiritualnya dengan bubb al-ilabi. Makanya, tidak mengherankan jika banyak ulama sezamannya kerap berkunjung ke kediamannya untuk mendiskusikan berbagai persoalan keagamaan. Bagi Rabi'ah, “cara yang paling baik untuk mendekatkan diri kepada Allah adalah bahwa dia harus tahu bahwa dia tidak boleh mencintai apapun di dunia ini atau di akherat nanti, selain Dia."7 Oleh sebab itu, saat dilamar oleh Gubernur Basrah, ia menolak karena tidak ingin cintanya kepada Allah terhalangi cintanya kepada makhluk. Untuk itu, ia senantiasa berdo'a dan bermunajat kepada Allah, Sang Kekasih, sepanjang waktu melalui bait-bait puisi nan indah. ${ }^{8}$

Perempuan sufi lainnya yang tercatat dalam sejarah, antara lain Nafisah (145 H$208 \mathrm{H}$ ), buyut Hasan bin Ali bin Abi Thalib yang terkenal dengan kemampuannya tentang al-Qur'an serta tafsirnya dan syair keagamaannya. Ada juga Sya’wanah,

III; Abu Wafa' al-Ghanimi al-Taftazani, Tasawnf Islam: Telaab Historis dan Perkembangannya (terj. Subkhan Anshori), (Jakarta: Gaya Media Pratama, 2008); M. Solihin, Sejarah dan Pemikiran Tasawuf di Indonesia, (Bandung: Pustaka Setia, 2001); Hawas Abdullah, Perkembangan Ilmu Tasanuf dan Tokoh-tokobnya di Nusantara, (Surabaya: alIkhlas, tt)

${ }^{6}$ Dalam dunia sufi, dikenal dua nama Rabi'ah, yakni Rabi'ah al-Adawiyah al-Qasyysyiyah, atau disebut juga Rabi'ah al-Adawiyah al-Bashriyah (tempatnya dilahirkan) dan Rabi'ah al-Adawiyah asy-Syiriahlm. Namun, dalam berbagai literatur tasawuf, hanya nama Rabi'ah al-Adawiyah al-Qisysyiyah (berjulukan Ummu al-Khair binti Ismail al-Adawiyah al-Qisysyiyah) yang disejajarkan dengan para guru sufi laki-laki. Lihat Sururin, "Perempuan dan Tarekat", hlm. 103.

7 Abu Abdurrahman al-Sulami, Sufi-sufi Wanita: Tradisi yang Tercadari, terj. Ahsin Muhammad, (Bandung: Pustaka Hidayah, 2004), hlm. 90. Lihat juga Javad Nurbakhsh, Wanita-wanita Sufi, terj. M.S. Nasrullah dan Ahsin Muhammad, (Bandung: Mizan, 1996)

8 Tentang Rabi'ah al-Adawiyah, banyak penulis yang sudah membuat biografinya, antara lain" juga Thaha Baqi Abdul al-Surur, Rabi'ah al-Adawiyah, (Kairo: Dar Fikri Arbi, 1957); Abdul Mun'im Zandil, Rabi'ah al-Adawiyah \& Mabuk Cintanya kepada Sang Khalik, terj. Mohammad Yusron, (Yogyakarta: Citra Media, 2007); An-Nabawi Jaber Siraj dan Abdussalam A. Halim Mahmud, Rabiah, Sang Obor Cinta: Sketsa Sufisme Wali Perempuan, terj. Thalib Haqqi, (Yogyakarta: Sabda Persada, 2003); Syekh "Ustman al-Kharbani, Kisab Cinta Rabiah al-Adaniyah, terj. A. Bahruddin Sholihin, (Jogjakarta: Diva Press, 2008), cet. VI; Margaret Smith, Rabi'ab: Pergulatan Spiritual Perempuan, terj. Jamilah Baraja, (Surabaya: Risalah Gusti, 1997). 
mantan budak kulit hitam yang dikenal karena kesedihan dan kesalehannya serta suaranya yang bagus dalam membaca ayat suci al-Qur'an dan syair, serta Fatimah (w. $233 \mathrm{H} / 838 \mathrm{M}$ ), salah satu ahli makrifat terbesar. ${ }^{9}$

Selain guru sufi perempuan, meskipun sedikit, tercatat juga perempuan wali di beberapa catatan resmi di berbagai wilayah, terutama di makam-makam, yang sering diziarahi untuk berbagai kepentingan. Dari banyak wilayah, India merupakan wilayah yang paling kaya dengan perempuan sufi wilayah dibandingkan dengan Anatolia, Iran, Afrika Utara, Pakistan, dan lainnya. Beberapa nama yang banyak dikenal, antara lain Jihannara (putri Syah Jihan) dan pembimbing mistiknya, Bibi Khatun (w. 1639M, seorang wali perempuan terkemuka dalam Thariqah Qadhiriyah di Punjab). ${ }^{10}$

Di Indonesia, tidak banyak dijumpai nama tokoh perempuan yang mengisi sejarah sosial intelektual-religi, khususnya di bidang tasawuf. ${ }^{11}$ Faktor utama yang menjadi penyebab adalah langkanya sumber-sumber tertulis. Sumber yang ada pun seringkali hanya berupa informasi masing-masing ulama atau catatan orang lain atau riwayat lisan (oral history) yang masih dipelihara oleh masyarakat. ${ }^{12}$ Selain itu, faktor kultural disinyalir juga berpengaruh besar, di mana posisi perempuan (masih)dianggap lebih rendah daripada laki-laki, yang karenanya: (1) tidak mendapat ruang dan waktu yang "wajar" untuk berperan, berkontribusi, dan berdedikasi, atau (2) mungkin juga "sengaja" tidak dimunculkan karena berbagai alasan.

Menurut Martin van Bruinessen, sesungguhnya perempuan merupakan bagian yang tidak bisa dipisahkan dari persoalan Thariqah, baik sebagai pengikut maupun sebagai pimpinan. ${ }^{13}$ Dari hasil penelusurannya, Bruinessen mencatat beberapa nama

\footnotetext{
${ }^{9}$ Sururin, "Perempuan dan tarekat"

${ }^{10}$ Annemarie Schimmel, Dimensi Mistik, hlm. 553-554.

${ }^{11}$ Di Indonesia, tarekat tidak bisa dilepaskan dari kehidupan keagamaan masyarakat Indonesia, bahkan bisa disebutkan bahwa tarekat sudah menjadi tradisi, terutama di kalangan pesantren. Lihat juga misalnya Zamakhsyari Dhofier, Tradisi Pesantren, (Jakarta: LP3ES, 1990).

12 Azyumardi Azra, dalam "Biografi Sosial Intelektual Ulama Perempuan: Pemberdayaan Historiografi”, dalam Jajat Burhanudin (ed.), Ulama Perempuan, (Jakarta: Gramedia, 2002), hlm. xxv.

${ }^{13}$ Menurut Martin van Bruinessen, dalam tarekat Naqsabandiyah saja diperkirakan jumlah murid perempuannya mencapai 30-40 persen. Lihat Martin van Bruinessen, Tarekat Naqsabandiyah di Indonesia, (Bandung: Mizan, 1998), cet. ke-5, hlm. 197-198.

Bahkan berdasarkan pengamatan Sururin, jumlah pengikut perempuan lebih banyak daripada pengikut laki-laki. Meskipun belum ada data statistik yang pasti akibat banyaknya jumlah tarekat dan belum terorganisasi dengan baik, namun berbagai even, seperti pengajian, menunjukkan fakta tersebut. Lihat Sururin, "Perempuan dan Tarekat", hlm. 110.
} 
Perempuan dalam Thariqah (Studi Terhadap Peran Perempuan Dalam Thariqah Tijaniyah Bangka)

mursyidah (perempuan yang menjadi pimpinan/tokoh Thariqah) dalam Thariqah Naqsabandiyah Mazhariyah Madura. Menurutnya, keberadaan mursyidah tersebut bukan hanya pelengkap, melainkan aktif dan mandiri dalam pelbagai aktivitas Thariqah. Mereka memiliki banyak pengikut yang tidak hanya di Madura, melainkan tersebar ke berbagai daerah, seperti Kalimantan Barat danMalang Selatan. Di antara mursyidah tersebut adalah Nyai Thobibah dan Syarifah Fathimah di Sumenep, serta Syarifah Noor (dikenal dengan nama Pah Nong) di Gondanglegi. ${ }^{14}$

Dalam Thariqah Tijaniyah pun demikian, ditemukan beberapa tokoh perempuan, bahkan ada yang menjadi muqaddam (pemimpin Thariqah, disebut dengan gelar khalifah) di Madura dan Jawa Barat (Kuningan dan Garut). Di Kuningan, sosok $\mathrm{Hj}$. Chamnah, meskipun tidak sepopuler tokoh-tokoh perempuan Indonesia kontemporer, sangat disegani karena memiliki preseden dalam perkembangan dunia sufi. Meskipun ketokohannya banyak dianggap lebih bersifat lokal (perdesaan) dan lingkup Thariqah Tijaniyah, kedudukannya sebagai muqaddam Thariqah Tijaniyah wilayah Kuningan menegaskan posisinya yang sangat penting. ${ }^{15}$

Sementara di Garut, meskipun bukan seorang mursyidah ataupun khalifah, bahkan tidak resmi menganut Thariqah Tijaniyah, masyarakat sangat mengenal sosok $\mathrm{Hj}$. Rd. Atikah sebagai seorang tokoh perempuan yang senantiasa mengacu pada nilai, moral, dan etik Thariqah Tijaniyah dalam setiap aktivitas dakwahnya (pengajian). Tokoh perempuan ini dikenal sangat fasih menyampaikan materi dakwah, runtut dalam pemikiran, sistematis dalam pembahasan, dan kharismatik. Jadi, tidak mengherankan jika aktivitas dakwahnya merambah hingga ke Malaysia, Singapura, dan Brunei Darussalam. $^{16}$

Lantas, bagaimana di Bangka? Berdasarkan informasi yang didapat, diketahui bahwa terdapat keberadaan sosok perempuan yang terlibat aktif dalam perkembangan

${ }^{14}$ Nyai Thobibah menerima ijazah penuh dari Kyai Ali Wafa, sedangkan Syarifah Fathimah (putri Habib Muhammad) dibaiat oleh Kyai Sirajuddin dan menerima ijazah penuh dari Kyai Syamsuddin Umbul. Martin van Bruinessen, Tarekat Naqsabandiyah

${ }^{15}$ Sururin, "Perempuan dan Tarekat", hlm. 109. Affandi Mochtar pernah menulisnya secara gamblang melalui tulisan berjudul "Ny. Hj. Chamnah: Tokoh Perempuan Tarekat Tijaniyah", dalam Jajat Burhanudin (ed.), Ulama Perempuan, (Jakarta: Gramedia-PPIM IAIN Jakarta, 2002).

${ }^{16}$ Sururin, "Perempuan dan Tarekat" 
Thariqah Tijaniyah di Pulau Bangka. ${ }^{17}$ Hal inilah yang membuat peneliti tergerak untuk menelusuri lebih jauh informasi tersebut (keberadaan tokoh perempuan yang berperan dan bagaimana peran tersebut mereka jalankan, serta kendala yang mereka hadapi untuk melaksanakan peran tersebut), di samping hal-hal lain yang berkaitan dengan perkembangan Thariqah Tijaniyah di Bangka.

\section{B. Tasawuf dan Ruang Lingkupnya}

\section{Pengertian Tasawuf}

Tasawuf secara etimologi diartikan berbeda-beda oleh para ahli, ada beberapa ahli menyatakan bahwa kata tasawuf diambil dari kata Shuffah artinya serambi tempat duduk. Maksudnya serambi masjid Nabawi di Madinah yang disediakan untuk orangorang yang belum mempunyai tempat tinggal dari kalangan Muhajirin di masa Rasulullah Saw. Mereka biasa dipanggil ahli shuffah (pemilik serambi) karena di serambi masjid itulah mereka bernaung. ${ }^{18}$

Selain itu diambil dari kata Shafa artinya bersih atau jernih. Bisa juga di sebut Shuf artinya bulu domba, disebabkan karena kaum sufi biasa menggunakan pakaian dari bulu domba yang kasar, sebagai lambing akan kerendahan hati mereka, juga menghindari sikap sombong, serta meninggalkan usaha-usaha yang bersifat duniawi. Orang yang berpakaian bulu domba disebut "mutashawwif", sedangakan perilakunya disebut " tasawuf ". 19 Tasawuf sendiri adalah upaya untuk membebaskan diri dari sifat-sifat kemanusiaan demi meraih sifat-sifat malaikat dan akhlak ilahi, serta menjalani hidup pada poros ma'rifatullah dan mahabbatullab sembari menikmati kenikmatan spiritual. Sedang sebuah ungkapan yang disematkan kepada para ahli tasawuf disebut sufi. ${ }^{20}$

\footnotetext{
${ }^{17}$ Menurut Zulkifli, jauh sebelum tarekat Tijaniyah masuk di Bangka, tarekat Sammaniyah dan Qadiriyah-Naqsyabandiyah telah lebih dulu berpengaruh dalam kehidupan keagamaan dan sosiokultural masyarakat Bangka. Lihat Zulkifli, Kontinuitas Islam Tradisional di Bangka, (Sungailiat: Shiddiq Press, 2007), hlm. $47-50$.

${ }^{18}$ Harun Nasution, Falsafat dan minisme dalam Islam, (Jakarta: Bulan Bintang, 1978), hlm. 18.

${ }^{19}$ Mustafa zahri, Kunci memahami Ilmu Tasawuf, (Surabaya: PT Bina ilmu, 1976), hlm. 83.

${ }^{20}$ Muhammad Fethullah Gülen, Kalbin Zümrüt Tepeleri, Terj. Fuad Syaifudin Nur, Tasawnf Untuk Kita Semua (Jakarta: Anggota IKAPI DKI Jakarta, 2014), hlm. 2.
} 
Perempuan dalam Thariqah (Studi Terhadap Peran Perempuan Dalam Thariqah Tijaniyah Bangka)

Dengan demikian dari segi kebahasaan tasawuf menggambarkan keadaan yang selalu berorientasi kepada kesucian jiwa, mengutamakan panggilan Allah, berpola hidup sederhana, mengutamakan kebenaran, dan rela berkorban demi tujuan-tujuan yang lebih mulia di sisi Allah. Sikap demikian pada akhirnya membawa seseorang berjiwa tangguh, memiliki daya tangkal yang kuat dan efektif terhadap berbagai godaan hidup yang menyesatkan.

Selain itu menurut pandangan para sufi tasawuf di definisikan sebagai berikut:

- Imam Qushayri, pengarang biografi Rasa'il menganggap tasawuf sebagai suatu kesucian yaitu kesucian kehidupan jasmani dan rohani. ${ }^{21}$

- Syeikh al-islam zakaria Ansari mengatakan bahwa tasawuf mengajarkan cara untuk menyucikan diri, meningkatkan moral dan membangun kehidupan jasmani dan rohani guna mencapai kebahagian abadi. Unsur utama tasawuf adalah penyucian jiwa, dan tujuan akhirnya adalah tercapainya kebahagiaan dan keselamatan abadi. ${ }^{22}$

- Syekh Abul Hasan asy-Syadzili (m. 1258) syekh sufi besar dari Afrika Utara, mendefinisikan tasawuf sebagai "praktik dan latiban diri melalui cinta yang dalam dan ibadah untuk mengembalikan diri kepada jalan Tuhan"." 23 Tasawuf adalah salah satu jalan yang diletakkan Tuhan di dalam lubuk Islam dalam rangka menunjukkan mungkinnya pelaksanaan rohani bagi jutaan manusia. ${ }^{24}$

- Abu 'l Hasan Nuri berkata:"Tasawuf adalah Penyangkalan atas semua kenikmatan untuk diri sendiri." Dengan kata lain tasawuf melepaskan kenikmatan jasmani yang tak sesuai dengan hukum islam. ${ }^{25}$

- Abu' Ali Qazwini berpendapat bahwa: "Tasawuf berarti tingkah laku yang baik. ${ }^{26}$

- Abu Sahl Sa'luki mendefinisikan tasawuf sebagai "Tingkah laku yang tidak menimbulkan protes. ${ }^{27}$

- Syaikh Ibnu Ajibah menjelaskan tasawuf sebagai ilmu yang membawa seseorang agar bisa dekat bersama dengan Allah swt. melalui penyucian rohani dan

\footnotetext{
${ }^{21}$ Abuddin Nata, Metodologi studi Islam, cet. 17 (Jakarta: Rajawali Pers, 2010), hlm. 15.

${ }^{22}$ Ibid., hlm. 25.

${ }^{23}$ Syeikh Fadhlullah Haeri, Belajar Mudah Tasawnf (Jakarta: Lentera Basritama, 1998), hlm. 2.

${ }^{24}$ Abuddin Nata, Metodologi Studi Islam (Jakarta: Raja Grafindo Persada, 2003), hlm. 241.

${ }^{25}$ Harun Nasution, Falsafat dan minisme dalam Islam, hlm. 34.

${ }^{26}$ Ibid., hlm. 35.

${ }^{27}$ Ibid., hlm. 37.
} 
mempermanisnya dengan amal-amal shaleh dan jalan tasawuf yang pertama dengan ilmu, yang kedua amal dan yang terakhirnya adalah karunia Ilahi. ${ }^{28}$

- Muhammad Ibn Al-Qassab Berpendapat, "Tasawuf adalah sifat yang baik, seorang yang memiliki sifat yang lebih baik adalah seorang sufi yang lebih baik. ${ }^{29}$

- Abu Muhammad Ruwaim berkata: "Tasawuf tak lain adalah penyerahan diri kepada kehendak Allah. ${ }^{30}$

Dengan demikian jelaslah bahwa menurut para ahli sufi yang terkenal, tasawuf tidak lain adalah penyucian akal dan kehendak hati. Penyucian ini berarti menghilangkan keinginan seseorang karena kehendak Allah. Hal ini berarti membangun dinding kokoh yang memisahkan antara diri yang sesungguhnya dan nafsu iblis untuk melawan Allah. Dengan kata lain ini berarti disiplin diri. Menghindari apa yang dilarang dan mengerjakan apa yang di perintahkan.

\section{Asal Usul Tasawuf}

Menurut Sejarah Jauh sebelum lahirnya agama islam, memang sudah ada ahli Mistik yang menghabiskan masa hidupnya dengan mendekatkan diri kepada TuhanNya; antara lain terdapat pada India Kuno yang beragam Hindu maupun Budha. Orang-orang mistik tersebut dinamakan Gymnosophists ${ }^{31}$ oleh penulis barat dan disebut al-hukama'ul uroh oleh penulis Arab. Yang dapat diartikan sebagai orang-orang bijaksana yang berpakaian terbuka. Hal tersebut dimaksudkan, karena ahli-ahli mistik orang-orang India selalu berpakaian dengan menutup separuh badannya.

Selain itu, menurut sejarah benih-benih tasawuf sudah ada sejak dalam kehidupan Nabi SAW. Hal ini dapat dilihat dalam perilaku dan peristiwa dalam hidup, ibadah dan pribadi Nabi Muhammad SAW. Sebelum diangkat menjadi Rasul, berhari -hari ia berkhalwat di gua Hira terutama pada bulan Ramadhan. Di tempat itu, Nabi banyak berdzikir bertafakur dalam rangka mendekatkan diri kepada Allah. Pengasingan diri Nabi di gua Hira ini merupakan acuan utama para sufi dalam melakukan khalwat. Sumber lain yang diacu oleh para sufi adalahkehidupan para

\footnotetext{
${ }^{28}$ Cecep Alba, Tasawnf dan Tarekat, Dimensi Esoteris Ajaran Islam ( Bandung: PT Remaja Rosdakarya, 2012), hlm. 11.

${ }^{29}$ Nasution, Harun, Falsafat dan minisme dalam Islam, hlm. 37.

${ }^{30}$ Ibid., hlm. 40.

${ }^{31}$ Muhammad Solikhin, Tradisi Sufi Dari Nabi (Yogyakarta: Cakrawala, 2009), hlm. 34.
} 
Perempuan dalam Thariqah (Studi Terhadap Peran Perempuan Dalam Thariqah Tijaniyah Bangka)

sahabat Nabi yang berkaitan dengan keteduhan iman, ketaqwaan, kezuhudan dan budi pekerti luhur. Oleh sebab itu setiap orang yang meneliti kehidupan kerohanian dalam Islam tidak dapat mengabaikan kehidupan kerohanian para sahabat yang menumbuhkan kehidupan sufi pada abad setelahnya. ${ }^{32}$

Hal itu diperkuat oleh keterangan bahwa sesungguhnya pengenalan tasawuf sudah ada dalam kehidupan Nabi saw., sahabat, dan tabi'in. Sebutan yang populer bagi tokoh agama sebelumnya adalah zähid, äbid, dan nāsik, namun term tasawuf baru dikenal secara luas di kawasan Islam sejak penghujung abad kedua Hijriah. Sebagai perkembangan lanjut dari ke-shaleh-an asketis (kesederhanaan) atau para zāhid yang mengelompok di serambi masjid Madinah. Dalam perjalanan kehidupan, kelompok ini lebih mengkhususkan diri untuk beribadah dan pengembangan kehidupan rohaniah dengan mengabaikan kenikmatan duniawi. Pola hidup ke-shaleh-an yang demikian merupakan awal pertumbuhan tasawuf yang kemudian berkembang dengan pesatnya. Fase ini dapat disebut sebagai fase asketisme dan merupakan fase pertama perkembangan tasawnf, yang ditandai dengan munculnya individu-individu yang lebih mengejar kehidupan akhirat sehingga perhatiannya terpusat untuk beribadah dan mengabaikan keasyikan duniawi. Fase asketisme ini setidaknya sampai pada dua Hijriah dan memasuki abad tiga Hijriah sudah terlihat adanya peralihan konkrit dari asketisme Islam ke sufisme. Fase ini dapat disebut sebagai fase kedua, yang ditandai oleh antara lain peralihan sebutan zāhid menjadi sufi. Di sisi lain, pada kurun waktu ini, percakapan para zăhid sudah sampai pada persoalan apa itu jiwa yang bersih, apa itu moral dan bagaimana metode pembinaannya dan perbincangan tentang masalah teoritis lainnya. ${ }^{33}$

Tindak lanjut dari perbincangan ini, maka bermunculanlah berbagai teori tentang jenjang-jenjang yang harus ditempun oleh seorang Sufi (al-maqāmat) serta ciriciri yang dimiliki oleh seorang sufi pada tingkat tertentu (al-häl). Demikian juga pada periode ini sudah mulai berkembang pembahasan tentang al-ma'rifat serta perangkat

\footnotetext{
${ }^{32}$ Al-Taftazani, Al-Taftazimi, SUFI dari zaman ke zaman, cet.II. (Pustaka: Bandung, 1976), hlm. 63.

${ }^{33}$ Rivay Siregar, Tasawnf dari sufisme klasik ke neo sufisme, (Jakarta: PT. RajaGrafindo Persada , Ed.2, Cet.2, 2004) hal.36-37
} 
metodenya sampai pada tingkat fana' dan ittihad. Bersamaan dengan itu, tampil pula para penulis tasawuf, seperti al-Muhāsibi (w. 243 H), al-Kharraj (w. 277 H.), dan alJunaid (w. 297 H) dan penulis lainya. Fase ini ditandai dengan munculnya dan berkembangnya ilmu baru dalam khazanah budaya Islam, yakni ilmu tasawuf yang tadinya hanya berupa pengetahuan praktis atau semacam langgam keberagamaan. Selama kurun waktu itu tasawuf berkembang terus ke arah yang lebih spesifik, seperti konsep intuisi, al-kasyf, dan dzawq. ${ }^{34}$

Pesatnya perkembangan tasawuf sebagai salah satu kultur ke-Islaman, nampaknya memperoleh infus atau motivasi dari tiga faktor. Infus ini kemudian memberikan gambaran tentang tipe gerakan yang muncul: Pertama: adalah karena corak kehidupan yang profan dan hidup kepelesiran yang diperagakan oleh ummat Islam terutama para pembesar dan para hartawan. Dari aspek ini, dorongan yang paling besar adalah sebagai reaksi dari sikap hidup yang sekuler dan gelamour dari kelompok elit dinasti penguasa di istana. Proses tersamar ini mereka lakukan dengan gaya murni etis, pendalaman kehidupan spiritual dengan motivasi etikal. Tokoh populer yang dapat mewakili aliran ini dapat ditunjuk Hasan al-Bahsri (w. $110 \mathrm{H}$ ) yang mempunyai pengaruh kuat dalam kesejarahan spiritual Islam, melalui doktrin al-zubd dan khawf - al-raja', Rabi'ah al-Adawiyah (w. $185 \mathrm{H}$ ) dengan ajaran al-hubb atau mahabbah serta Ma'ruf al-Kharki (w. 200 H) dengan konsepsi al-syawq sebagai ajarannya. Nampaknya setidaknya pada awal munculnya, gerakan ini semacam gerakan sektarian yang interoversionis, pemisahan dari trend kehidupan, eksklusif dan tegas pendirian dalam upaya penyucian diri tanpa memperdulikan alam sekitar.

Kedua: timbulnya sikap apatis sebagai reaksi maksimal kepada radikalisme kaum khawarij dan polarisasi politik yang ditimbulkannya. Kekerasan pergulakan politik pada masa itu, orang-orang yang ingin mempertahankan ke-shaleh-an dan ketenangan rohaniah, terpaksa mengambil sikap menjauhi kehidupan masyarakat ramai untuk menyepi dan sekaligus menghindarkan diri dari keterlibatan langsung dalam pertentangan politik. Sikap yang demikian itu melahirkan ajaran 'u§lah yang dipelopori oleh Surri al-Saqathi (w. 253 H). Apabila diukur dari kriteria sosiologi, nampaknya

${ }^{34}$ Ibid, hlm. 37.

Scientia: Jurnal Hasil Penelitian, Vol. 4, No. 2 (2019) | 191 
Perempuan dalam Thariqah (Studi Terhadap Peran Perempuan Dalam Thariqah Tijaniyah Bangka)

kelompok ini dapat dikategorikan sebagai gerakan "sempalan", satu kelompok ummat yang sengaja mengambil sikap 'uzlah kolektif yang cenderung ekslusif dan kritis tehadap penguasa. ${ }^{35}$

Dalam pandangan ini, kecenderungan memilih kehidupan rohaniah mistis, sepertinya merupakan pelarian, atau mencari konpensasi untuk menang dalam medan perjuangan duniawi. Ketika di dunia yang penuh tipu daya ini sudah kering dari siraman cinta sesama, mereka bangun dunia baru, realitas baru yang terbebas dari kekejaman dan keserakahan, dunia spiritual yang penuh dengan salju cinta. Faktor ketiga, tampaknya adalah karena corak kodifikasi hukum Islam dan perumusan ilmu kalam yang rasional sehingga kurang bermotivasi etikal yang menyebabkan kehingan moralitasnya, menjadi semacam wahana tiada isi atau semacam bentuk tanpa jiwa. Formalitas faham keagamaan dirasakan semakin kering dan menyesakkan rüh al-dìn yang menyebabkan terputusnya komunikasi langsung suasana keakraban personal antara hamba dan penciptanya. Kondisi hukum dan teologis yang kering tanpa jiwa itu, karena dominannya posisi agama dalam agama, para zubüdan tergugah untuk mencurahkan perhatian terhadap moralitas, sehingga memacu penggeseran asketisme ke-shaleh-an kepada tasawuf. ${ }^{36}$

Apabila dilihat dari sisi tasawuf sebagai ilmu, maka fase ini merupakan fase ketiga yang ditandai dengan dimulainya unsur-unsur di luar Islam berakulturasi dengan tasawuf. Ciri lain yang penting pada fase ini adalah timbulnya ketegangan antara kaum orthodoks dengan kelompok sufi berfaham ittihad di pihak lain. ${ }^{37}$

Akibat lanjut dari pembenturan pemikiran itu, maka sekitar akhir abad ketiga Hijriah tampil al-Karraj (w. 277 H) bersama al-Junaid (w. 297 H) menawarkan konsepkonsep tasawuf yang kompromistis antara sufisme dan orthodoksi. Tujuan gerakan ini adalah untuk menjembatani atau bila dapat untuk mengintegrasikan antara kesadaran mistik dengan syariat Islam. Jasa mereka yang paling bernilai adalah lahirnya doktrin al-baqa' atau subsistensi sebagai imbangan dan legalitas al-fana'.hasil keseluruhan dari usaha pemaduan itu, doktrin sufi membuahkan sejumlah besar pasangan-pasangan

\footnotetext{
${ }^{35}$ Ibid, hlm. 37-38.

${ }^{36}$ Ibid, hlm. 38.

${ }^{37}$ Ibid, hlm. 41.
} 
kategori dengan tujuan memadukan kesadaran mistik dengan syariah sebagai suatu lembaga. Upaya tajdid itu mendapat sambutan luas dengan tampilnya penulis-penulis tasawuf tipologi ini, seperti al-Sarraj dengan al-Luma,al-Kalabasi dengan al-Ta'arruf li Maz̧hähib Abl al-Tasawuf dan al-Qusyairi dengan al-Risälah ${ }^{38}$

Sesudah masanya ketiga sufi ini, muncul jenis tasawuf yang berbeda, yaitu tasawnf yang merupakan perpaduan antara sufisme dan filsafat sebagai hasil pikir Ibnu Masarrah (w. $381 \mathrm{H}$ ) dengan konsepsinya ma'rifat sejati, sebagai gabungan dari sufisme dan teori emanasi Neo- Platonisme. Gagasan ini, sesudah masa al-Gazali dikemBangkan oleh Suhrawardi al-Maqtūl (w. 578 H) dengan doktrin al-Isyräkìyah atau illuminasi. Gerakan orthodoksi sufisme mencapai puncaknya pada abad lima Hijriah memalui tokoh monumental al-Gazali (w. 503 H). Dengan upayanya mengikis semua ajaran tasawuf yang menurutnya tidak Islami. Sufisme hasil rekayasanya itu yang sudah merupakan corak baru, mendapat tempat yang terhormat dalam kesejahteraan pemikiran ummat Islam. Cara yang ditempuhnya untuk menyelesaikan pertikaian itu, adalah dengan penegasan bahwa ucapan ekstatik berasal dari orang arif yang sedang dalam kondisi sakr atau terkesima. Sebab dalam kenyataanya, kata al-Gazali, setelah mereka sadar mereka mengakui pula, bahwa kesatuan dengan Tuhan itu bukanlah kesatuan hakiki, tetapi kesatuan simbolistik.

Pendekatan yang dilakukan oleh al-Gazali, nampaknya bagi satu pihak memberikan jaminan untuk mempertahankan prinsip bahwa Allah dan alam ciptaanNya adalah dua hal yang berbeda, sehingga satu sama lain tidak mungkin bersatu. Di pihak lain memberikan kelonggaran pula bagi para sufi untuk memasuki pengalamanpengalaman ke-sufi-an puncak itu tanpa kekhawatiran dituduh kafir. Gambaran ini menunjukkan tasawuf sebagai ilmu telah sampai ke fase kematangannya atau memasuki fase keempat, yang ditandai dengan timbulnya dua aliran tasawuf, yaitu tasawuf sunni dan tasawuf filsafati. ${ }^{39}$

\footnotetext{
${ }^{38}$ Ibid, hlm. 41-42.

${ }^{39}$ Ibid, hlm. 43.
} 
Perempuan dalam Thariqah (Studi Terhadap Peran Perempuan Dalam Thariqah Tijaniyah Bangka)

\section{Fungsi Tasawuf}

Tasawuf merupakan sebuah dimensi keilmuan yang dapat diamalkan menjadi sebuah perbuatan dalam kategori ibadah. sering disebut dengan Ilmu tasawuf yang maksudnya ilmu yang mempelajari usaha membersihkan diri, berjuang memerangi hawa nafsu, mencari jalan kesucian dengan ma'rifat menuju keabadian, saling mengingatkan antara manusia, serta berpegang teguh pada janji Allah Swt dan mengikuti syari'at Rasulullah saw. Dalam mendekatkan diri dan mencapai riḍhaNya. ${ }^{40}$

Dengan kata lain, tasawuf sendiri dipahami sebagai upaya untuk membebaskan diri dari sifat-sifat kemanusiaan demi meraih sifat-sifat malaikat dan akhlak ilahi, serta menjalani hidup pada poros ma'rifatullah dan mahabbatullah sembari menikmati kenikmatan spiritual. Sedang sebuah ungkapan yang disematkan kepada para ahli tasawuf disebut sufi. ${ }^{41}$ Tujuan para sufi adalah ma'rifatullah yang dalam perjalanannya melalui beberapa tahap seperti syariat, țarīqah, hakekat dan ma'rifat. Ma'rifat adalah tujuan akhir dari tasawwuf, yang mana didikannya pun berpindah dari hakekat ke ma'rifat yaitu mengenal Tuhan sebaik-baiknya. ${ }^{42}$

\section{Sumber-sumber ajaran Tasawuf}

Menurut Prof. Louis Massignon, seorang orientalis perancis sebagaimana terurai dalam karyanya, essai sur les origines du lexique technique de la mystique musulmane. Dalam kajiannya itu dia sampai pada kesimpulan, bahwa Sumber Tasawuf itu empat: ${ }^{43} 1$ ) Alquran sebagai sumber yang terpenting. Sebagaimana dijelaskan dalam islam bahwa Al-Qur an dan Al-Hadits merupakan kerangka acuan pokok ketika hendak menerima atau menemukan persoalan-persoalan baru atau persoalan-persoalan unik yang mereka temui, termasuk dalam pembahasan tasawuf; ${ }^{44}$ 2) Ilmu-ilmu Islam, seperti Hadist, Fiqh, Nahwu, dan turunannya; 3) Terminologi-terminologi para ahli ilmu kalam angkatan pertama; 4) Bahasa ilmiah yang terbentuk di timur sampai enam abad

\footnotetext{
${ }^{40}$ Rosihon Anwar, Akblak Tasawuf, (Bandung: Pustaka Setia, 2010), hlm. 147.

${ }^{41}$ Muhammad Fethullah Gülen, Kalbin Zümrüt Tepeleri, Terj. Fuad Syaifudin Nur, Tasawnf Untuk Kita Semua, (Jakarta: Anggota IKAPI DKI, 2014), hlm. 2.

${ }^{42}$ Abu Bakar Aceh, Sejarah Filsafat Islam, (Bandung: Ramadan, 1991), hlm. 406.

${ }^{43}$ Abbas, Arifin Ilmu Tasawuf, hlm. 35.

${ }^{44}$ Rosihon Anwar, Akblak Tasawuf, hlm. 151.
} 
permulaan adalah dari bahasa lainnya, seperti bahasa bahasa yunani dan persia, yang menjadi bahasa ilmu pengetahuan dan filasafat.

Tasawuf, seperti telah dikemukakan diatas, pada awal pembentukan disiplinnya adalah moral keagamaan. Jelas sumber pertamanya adalah ajaran-ajaran islam, sebab tasawuf di timba dari Al-Quran dan As-Sunnah dan amalan serta ucapan para sahabat. Dari Al-Quran dan As-sunnah itulah para sufi, pertama-tama mendasarkan pendapat mereka tentang moral dab tingkah laku. Juga latihan-latihan rohaniah mereka. Menurut Al-Thusi dalam kitab al-luma mengemukakan bagaimana para sufi secara khusus lebih menaruh perhatian terhadap moral lurur serta sifat dan amalan utama. Hal ini demi mengikuti Nabi, dan para sahabatnya, serta orang-orang setelah beliau.

\section{Perempuan Dalam Thariqah Tijaniyah di Bangka}

Berdasarkan buku yang diajarkan kepada para pengikut Thariqah Tijani di pulau Bangka, di pahami buku yang diajarkan ${ }^{45}$ ialah yang ditulis oleh M. Yunus Hamid tentang "Thariqah at-Tijaniyah", dari asal katanya thariqah diambil dari kata benda thariq yang berarti jalan. di arab thariq mempunyai pengertian jalan besar atau jalan tol antar kota. kata thariqah juga mempunyai arti lain yakni cara atau metode dalam melakukan sesuatu. namun dimasyarakat tariqah dikenal dengan Thariqah. Thariqah ini dipahami dengan jalan/ cara/ metode implementasi syariat. yaitu cara yang ditempuh oleh seseorang dalam menjalankan syariat islam, sebagai upaya yang dilakukan dalam hal mendekatkan diri kepada Allah SWT. Sehingga dapat dipahami bahwa orang yang berthariqah ialah orang yang melaksanakan hukum syariat. lebih jelasnya syariah dipahami sebagai hukum teoritis dan thariqah dipahami sebagai praktek pelaksanaannya. $^{46}$

Selanjutnya guru Aruf mengatakan bahwa Thariqah di bagi menjadi dua macam: Pertama, thariqah secara bahasa, bukan thariqah yang dimaksudkan oleh kaum sufi. thariqah ini disebut tariqah 'Aam yaitu melaksakan hukum Islam sebagaimana

\footnotetext{
${ }^{45}$ Wawancara dengan mukaddam (Guru Aruf) untuk wilayah provinsi kepulauan Bangka Belitung.

${ }^{46}$ Wawancara dengan mukaddam (Guru Aruf) untuk wilayah provinsi kepulauan Bangka Belitung. Dengan pedoman buku karangan M Yunus Hamid, V M. Yunus A. Hamid, Thariqah AT Tijaniyah dalam neraca AlQur'an dan As Sunnah: Tanya Jawab., (Jakarta: Yayasan Pendidikan dan Dakwah Tarbiyah AT Tijaniyah: 2017), hlm. 38-39.
} 
Perempuan dalam Thariqah (Studi Terhadap Peran Perempuan Dalam Thariqah Tijaniyah Bangka)

masyarakat pada umumnya yakni melaksanakan semua perintah, menjauhi semua larangan islam dan anjuran-anjuran sunnah serta berbagai ketentuan hukum lainnya sebatas pengetahuan dan kemampuan tanpa ada bimbingan khusus dari guru/Mursyid/mukaddam. Kedua, thariqah secara istilah kaum sufi disebut thariqah khas, yaitu melaksanakan hukum syariat islam melalui bimbingan lahir menjelaskan secara intensif tentang hukum-hukum islam dan cara pelaksanaannya secara benar. kemudian bimbingan batin adalah tarbiyah rohani dari seorang guru/ mursyid/ mukaddam dengan bai'at khusus izin sanadnya sampai kepada Rasulullah SAW. thariqah khas ini dikenal dengan nama thariqah as sufiyah atau thariqah 'Auliya disebut juga dengan nama Thariqah alm'tabarah. ${ }^{47}$

Lebih kongkritnya thariqah dalam istilah tatanan ilmu tasawuf ini mempunyai arti metode pendekatan diri kepada Allah SWT melalui amalan-amalan yang dikerjakan secara rutin. amalan tersebut harus bersumber dari al-qur'an dan hadis (ma'tsur), yang diterima syarat dan rukun tertentu melalui ijazah atau baiat dengan silsilah bersambung kepada Nabi Muhammad SAW. Sedangkan amalan yang sanadnya tidak tersambung kepada Rasulullah itu bukan termasuk thariqah. Thariqah sufiyah yang sanadnya bersambung kepada Rasulullah SAW berjumlah 360 thariqah. sedangkan menurut pendapat dari sumber yang lain mengatakan 313 thariqah. kemudian thariqah sufiyah masuk Indonesia yang direkomendasikan oleh Nahdlatul Ulama sebanyak 44 thariqah, dikenal dengan thariqah Al Mu'tabarah An Nahdiliyah dengan wadah Organisasi yang bernama Jami'ah Ablu Al Thariqah Al Mu'thabarah Al Nabdiyab ${ }^{48}$.

Thariqah Tijaniyah di Bangka merupakan Thariqah dengan pengikut paling banyak. perkembangan dan eksistensi Thariqah Tijaniyah tidak lepas dari adanya pengikut dari kalangan perempuan. Bahkan dapat dikatakan bahwa lebih banyak kalangan perempuan yang mengikuti Thariqah Tijaniyah. Dari itu, penting untuk menghadirkan sosok yang tepat dari kalangan mereka sendiri untuk bisa memberikan bimbingan secara langsung.

\footnotetext{
${ }^{47}$ Ibid,

${ }^{48}$ Ibid, hlm. 40.
} 
Sosok perempuan pada Thariqah Tijaniyah di Bangka belum memliki seorang mukaddam sebagaimana yang ada disebagian tempat-tempat lain. Walaupun demikian, bukan berarti tidak ada sosok perempuan yang berperan penting dalam dakwah pada Thariqah Tijaniyah. Adapun sosok perempuan yang diberikan amanah oleh mukaddam yakni perempuan yang memiliki akhlak yang baik tidak meninggalkan solat lima waktu dan menguasai ilmu yang fardu a'in. Selain itu, yakni perempuan yang menguasai amalan dan pemahaman tentang Thariqah Tijaniyah, serta sosok perempuan yang sudah masuk kedalam syarat-syarat seorang pengikut thariqah atau syarat-syarat masuk thariqah.

Adapun beberapa hal yang menjadi syarat bagi yang ingin mengikuti thariqah At Tijaniyah: 1) apabila sudah memeliki thraiqah sebelumnya maka wajib melapaskannya; 2) Muqaddam yang mentalkinnya telah mendapatkan izin yang sah (dari Muqaddam yang berhak melantik muqaddam) untuk memberikan wirid; 3) di baiat mendapatkan izin mengamalkan wirid.

Selain itu sosok tokoh perempuan di pulau Bangka yang dimaksud yakni sosok perempuan yang disebutkan oleh mukkaddam bahwa dari segi perbuatan yang terlihat dapat menhindari dari hal-hal yang wajib dihindari oleh seorang pengamal thariqah Tijaniah. yang wajib dihindari yang dimaksdu yakni: 1) tidak boleh mengambil dan mengamalkan wirid thariqah lain selain wirid thariqah at Tijaniyah; 2) tidak boleh meninggalkan (berhenti) mengamalkan wirid thariqah at Tijaniyah dengan sengaja denganmengingkari kewajiban atas wirid tersebut; 3) tidak boleh mencaci, benci dan memusuhi Sayyidi Syeikh Ahmad At Tijani. ra; 4) tidak boleh ziarah kepada manapun yang bukan tijany; 5) tidak boleh memberikan wirid thariqah at Tijaniyah kepada orang lain tanpa izin yang sah untuk memberikan (sebelum dilantik jadi muqaddam); 6) tidak boleh meremehkan wirid at thariqah at Tijaniyah, seperti mengahirkan waktunya tanpa udzur syar'i atau mengerjakan secara asal asalan; 7) Tidak boleh memutuskan hubungan dengan siapapun tanpa ada izin syar'i terutama dengan ikhwan thariqah at tijani tidak boleh merasa aman dari makrillah (ancaman murka Allah).

Dari itu kemudian sosok tokoh perempuan ini menjadi penting dapat menjadi tauladan bagi para pengikut thariqah baik yang perempuan maupun laki-aki. 
Perempuan dalam Thariqah (Studi Terhadap Peran Perempuan Dalam Thariqah Tijaniyah Bangka)

Kehadiran perempuan yang menjadi tulang punggung juru dakwah Thariqah Tijaniyah dihadirkan dari kalangan mereka sendiri. Mereka merupakan perempuan yang mempuni untuk menjalankan peran sebagai seorang pembimbing dan penasehat sekaligus memberikan ketenangan batin dapat memecahkan masalah yang dihadapi oleh perempuan. Perempuan-perempuan ini menjadi sosok perpanjangan tangan dari mukaddam laki-laki dalam membimbing dan memberikan pemahaman hukum syariat islam di kalangan perempuan.

Sosok perempuan yang dipercaya oleh mukaddam bukan hanya dari para istri sang mukaddam melainkan memang sesuai dengan kriteria yang telah disebutkan dia atas. Menjadi penting hadirnya sosok penyemangat dan pemecah persoalan yang terjadi dikalangan perempuan. Sehingga tidak ada rasa sungkan untuk bertanya dan berkeluh kesah mengenai persoalan yang sedang dihadapi. Sosok yang lemah lembut dan karismatik hadir menyerupai sang ibu bagi kaum perempuan pengikut Thariqah Tijaniyah. Sosok yang lemah lembut memimpin perkumpulan di kalangan majelis ilmu yang diikuti dari kalangan perempuan.

Eksistensi Thariqah Tijaniyah diBangka ini memang tidak dapat dipisahkan dari sosok perempuan-perempuan yang mewakili mukaddam. Walapun, tidak terlihat jelas namun sangat dirasakan kehadirannya. Karena mereka berperan sebagai wakil dari mukaddam dalam hal menjadi penyambung lidah dalam membai'at perempuanperempuan yang inggin mengikuti Thariqah Tijaniyah. Berbicara Thariqah tentunya tidak bisa lepas dari orang yang berhak membaiat mengesahkan mereka untuk mengamalkan wirid-wirid Tijaniyah.

Walaupun belum adanya mukaddam dari kalangan perempuan, tetapi perempuan turut menjadi salah satu aktor dalam mempertahankan eksistensi Thariqah Tijaniyah di pulau Bangka. Perempuan memiliki peran yang cukup sentral. Adapun peran perempuan yang dimaksud mereka menjalankan peran sebagai pembimbing. Mereka memberikan bimbingan kepada pengikut Thariqah Tijaniyah di kalangan perempuan. Adapun pembimbingan ini didasarkan atas perpanjangan tangan dari mukaddam. Artinya bahwa perempuan ini dipilih langsung oleh mukaddam sehingga dapat mengemban tugas sebagai penyambung lidah. Selain itu perempuan juga 
berperan secara langsung dalam berdakwah dikalangan keluarga masing-masing baik untuk suami, anak, ayah, ibu dan kerabat dekat. Melalui pembimbingan dari kalangan perempuan ini diharapkan bisa mengikuti hukum syariat islam secara kaffah. Tentunya hal itu upaya membumikan Thariqah tijaniayah dikalangan masyarakat Bangka.

Tidak lepas dari pada itu, Agama Islam memiliki kaitan erat dengan kekuatan dan simbol yang dianut dalam konsepsi masyarakat, islam menjadi sebuah realitas dalam keberagamaan masyarakat di indonesia. Yang mana perempuan memiliki peran dalam Thariqah tijani bukan Thariqah yang tertutup untuk umum artinya pengajian atau bimbingan yang diberikan oleh perempuan yang bertorikat tijani dapat diikuti oleh siapa saja tanpa terkecuali. Tokoh perempuan berperan sebagai pembimbing lahir maupun batin para pengikut thariqah. Bimbingan lahir yang dilakukan oleh tokoh perempuan sebagai upaya untuk menjelaskan secara intensif tentang hukum-hukum islam yang harus diketahui dan di pahami sehingga dapat lakasanakan secara benar oleh para pengikut Thariqah. Kemudian tokoh perempuan ini juga memberikan bimbingan batin sebagai upaya memberikan pendidikan bagi jiwa para pengikut Thariqah tijani.

Keberlangsungan Thariqah dipulau Bangka bukan tanpa tantangan dan hambatan, adapun beberapa hambatan yang di alami dikalangan perempuan yakni untuk bisa menjadi akhwat yang diakui berThariqah tijani dibuktikan dengan bai'at yang dilakukan oleh seorang guru/Syeikh/Mursyid/Mukaddam yang membimbing langsung lahir dan batin akhwat yang inggin berthariqah tijani sehingga diharapkan mampu melaksanakan hukum islam secara menyeluruh. ${ }^{49}$ Dari hal itu yang menjadi sebuah problem yakni beberapa kalangan perempuan Bangka masih terasa sungkan untuk mendapatkan bai'at langsung dari mukaddam laki-laki. Hal ini sebagai sebuah konsekuensi dari belum adanya mukaddam perempuan di Bangka. ${ }^{50}$

Masyarakat Belum memahami tentang Thariqah tijani, sehingga muncul sifat jahil dan hasad $/$ iri. $^{51}$ Selain itu, memunculkan pemahaman dan pandangan yang keliru

${ }^{49}$ M. Yunus A. Hamid, Thariqah AT Tijaniyah dalam neraca Al Qur'an dan As Sunnab: Tanya Jawab., (Jakarta: Yayasan Pendidikan dan Dakwah Tarbiyah AT Tijaniyah: 2017), hlm. 40.

${ }^{50}$ Wawancara dengan mukaddam (Guru Aruf) untuk wilayah provinsi kepulauan Bangka Belitung.

${ }^{51}$ Wawancara dengan mukaddam (Guru Aruf) untuk wilayah provinsi kepulauan Bangka Belitung. 
Perempuan dalam Thariqah (Studi Terhadap Peran Perempuan Dalam Thariqah Tijaniyah Bangka)

dari masyarakat Bangka. Pertentangan pemahaman dan pandangan dengan sesama muslim yang menganggap Thariqah tijani tidak penting dan sesuatu perbuatan sesat termasuk dalam kategori kegiatan yang bid'ah. Diperparah lagi, sebagian masyarakat beranggapan bahwa semestinya orang yang ikut Thariqah itu tidak lagi bekerja disektor pemerintahan karena disitu terdapat aliran uang subhat sehingga dapat merusak kemurnian jiwa seorang sufi. Sementara Thariqah adalah murni penghambaan kepada allah atas dasar mahabbah. Tidak lagi berperilaku menjalankan kehidupan yang masih mengandung unsur keburukan apalagi cinta dunia semestinya semua yang dilakukan harus sesuai syari'at dan mahabbah rasa syukur yang mendalam.

Bahwa orang yang mengikuti Thariqah hidupnya harus jauh dari keramian, halhal bersifat duniawi benar-benar mengikuti life style para sufi. Pertentangan pemahaman dan tuduhan yang bahkan mengarah kepada konflik laten antar sessama umat islam. Hal semacam ini tentunya bukan sesuatu yang baik bagi perkembangan Thariqah tijani dikalangan perempuan. Selain itu ada anggapan bahwa Thariqah belum sepantasnya di implementasikan di masyarakat Bangka yang notabene masih jauh dari cara hidup orang sufi.

Selain itu menjadi penting untuk dipahami bahwa terdapat kontradiski yang mencolok pada pengikut Thariqah Tijaniyah di Bangka. Pada satu sisi Thariqah Tijaniyah menjadi Thariqah dengan pengikut yang terus berkembang. Perkembangan ini tidak di ikuti oleh masyarakat yang hidup di wilayah perkotaan. Karena perkotaan masih memperlihatkan sebuah agama sebagai kekuatan yang utuh dengan berbagai simbol-simbolnya. Sedangkan pada masyarakat pinggiran atau pedesaan itu semua menjadi sesuatu yang tidak begitu penting dengan simbol-simbol agamawan, yang terpenting yakni pengamalan agama dengan cara sederhana dan bersahaja.

Dari persoalan yang sedang dihadapi itu, menuntut para tokoh-tokoh penting pada Thariqah Tijaniyah untuk mengambil sikap dan tindakan. Namun diluar kebiasaan yang dilakukan justru hal-hal semacam itu di anggap bukan sebagai sebuah ancaman atau permasalahan di kalangan pengikut Thariqah Tijaniyah. Adapun cara agar perempuan dapat menyikapi dan mengatasi problem tersebut pada kalangan perempuan, Pertama para mukaddam memberikan bimbingan kepada perempuan yang 
diberikan kepercayaan untuk membimbing perempuan-perempuan pengikutnya agar menyampaikan bahwa hal-hal semacam itu tidak perlu diatasi, karena merupakan bagian dari tantangan bahwa mereka belum memahami terkait dengan Thariqah ${ }^{52}$. Selama belum adanya tindakan radikal yang secara nyata dilakukan oleh masyarakat Bangka terhadap perempuan-perempuan yang ber-Thariqah. Kedua, Perempuan yang dipercayai memberikan bimbingan penguatan konsep hidup, bahwa hidup tidak hanya persoalan penilaian manusia. Banyak hal yang dinilai manusia salah sejatinya itu sebuah kebenaran ataupun sebaliknya. Dalam arti lain yang terpenting adalah selama masih mengikuti keyakinan berdasarkan hukum syariat islam maka tidak perlu takut untuk ber-Thariqah. Mengikuti Thariqah sebuah jalan kebahagiaan yang hakiki.

Terlepas dari itu semua, eksistensi dan perkembangan yang semangkin meningkat pada pengikut Thariqah tijani diBangka ternyata tidak di ikuti oleh pengakuan secara mutlak dari para kholifah di tingkat nasional untuk mengangkat perempuan sebagai seorang mukaddam. Selain itu, tidak terlepas dari persoalan kaderisasi yang ada pada pengikut Thariqah tijani itu sendiri.

Kaderisasi pada Thariqah Tijani di masyarakat Bangka, secara jelas tidak ada istilah kaderisasi dalam mempertahankan eksistensinya. Oleh karena kaderisasi sesusatu yang di rasa tidak terlalu penting. Dikatakan bahwa mengajak masyarakat untuk mengikuti Thariqah tidak pernah dilakukan. Mengatakan diri seseorang mukadam sudah di angkat menjadi seorang mukaddampun tidak pernah dilakukan. Dengan kata lain para pengikut Thariqah Tijaniyah baik ketika berintraksi dengan sosial masyarakat atapun dalam konteks pengajian yang dapat di ikuti oleh khalayak umum, tidak pernah mengatakan kami ber-Thariqah Tijaniyah kemudian tidak pernah mengajak masyarakat untu mengikutinya. Apalagi seperti yang dilakuakan oleh para pengikut jama'ah tabligh yang mengunjungi dari rumah kerumah. Namun, upayaupaya berdakwah untuk menyampaikan hukum syariat islam di masyarakat menjadi sesuatu ynag tidak bisa ditinggalkan. Hal ini tidak lebih merupakan bagian dari pengamalan Thariqah Tijaniyah bukan dalam rangka melakukan kaderisasi.

\footnotetext{
${ }^{52}$ Wawancara dengan mukaddam (Guru Aruf) untuk wilayah provinsi kepulauan Bangka Belitung.
} 
Perempuan dalam Thariqah (Studi Terhadap Peran Perempuan Dalam Thariqah Tijaniyah Bangka)

Walaupun tidak adanyanya kaderisasi secara jelas dikalangan pengikut bukan berarti membuat Thariqah ini menjadi lemah dan hilang. Hingga hari ini Thariqah Tijaniyah terus berkembang karena siapa yang mengikuti Thariqah mendapatkan ketenagan dan kebahagiaan yang mutlak, mendapatkan anugrah dari Allah. Hanya saja dakwah dilakukan melalui pengajian-pengajian dimasjid-masjid. Karena eksis atau tidaknya Thariqah bukanlah misi utama dari terakat, melainkan menjadi jalan menggapai keselamatan dunia dan akherat. Dengan cara melaksanakan semua perintah, menjauhi semua larangan Islam dan anjuran-anjuran sunnah serta berbagai ketentuan hukum lainnya serta dengan nilai-nilai mahabbah kepada Allah SWT.

Walapun keberlangsungan Thariqah tidak menjadi sesuatu hal yang penting akan tetapi dakwah menjadi sesuatu yang pasti diperlukan bagi eksistensi islam untuk memberikan pencerahan sehingga tercapai keselamatan. Salah satu cara mencapai selamat yakni dengan mengikuti Thariqah Tijaniyah.

\section{Catatan Penutup}

Setelah melakukan penelitian secara seksama terhadap peran tokoh perempuan dalam thariqah Tijaniyah di pulau Bangka dapat ditarik kesimpulan:

1. Sosok tokoh perempuan dalam toriqah Tijaniyah yakni seorang perempuan yang mengamalkan thariqah syar'iyah yang memiliki lahir dan batin yang baik.

2. Tokoh perempuan dalam tariqah Tijaniyah berperan sebagai juru dakwah, tauladan yang baik, pembimbing, pemecah masalah keseharian para pengikut thariqah kaum perempuan dan perpanjangan lidah dari mukadam ikhwan yang berijazah.

3. kendala yang dihadapi adanya pertentangan pemahaman dan belum yakinnya masyarakat dengan tariqat Tijaniyah.

4. problem yang terjadi dalam thariqah tidak perlu ditakuti karena itu tidak perlu dirisaukan kaena itu bukanlah suatau ancama.

5. dalam thariqah Tijaniyah diBangka tidak ada kaderisasi secara khusus untuk membentuk muqaddam darikalangan perempuan, namun perempuan yang terpilih itu murni langsung petunjuk dari sang mukaddam di atasnya. 


\section{DAFTAR PUTAKA}

Al-Qur'an dan Terjemahnya1990. Jakarta: Departemen Agama - Kerajaan Saudi Arabia

A. Bachrun Rifa'i dan Hasan Mud'is. 2010 .Filsafat Tasawnf. Bandung: CV. Pustaka Setia

Abdul Mun'im Zandil. 2007. Rabi'ah al-Adawiyah \& Mabuk Cintanya kepada Sang Khalik (terj. Mohammad Yusron).Yogyakarta: Citra Media

Abu Abdurrahman al-Sulami. 2004. Sufi-sufi Wanita: Tradisi yang Tercadari(terj. Ahsin Muhammad). Bandung: Pustaka Hidayah

Abu Bakar Aceh. 1991. Sejarah Filsafat Islam. Bandung: Ramadan

Abuddin Nata. 2006. Akblak Tasawuf. Jakarta: PT RajaGrafindo Persada

Abu Wafa' al-Ghanim al-Taftazani. 2008. Tasawuf Islam: Telaah Historis dan Perkembangannya (terj. Subkhan Anshori).Jakarta: Gaya Media Pratama

Abuddin Nata. 2003. Metodologi Studi Islam. Jakarta: Raja Grafindo Persada

----. 2010. Metodologi studi Islam. Jakarta: Rajawali Pers

Al-Taftazani. 1976. Sufi dari zaman ke zaman. Bandung: Pustaka

An-Nabawi Jaber Siraj dan Abdussalam A. Halim Mahmud. 2003.Rabi'ah, Sang Obor Cinta: Sketsa Sufisme Wali Perempuan (terj. Thalib Haqqi).Yogyakarta: Sabda Persada

Annemarie Schimmel. 2003.Dimensi Mistik dalam Islam (terj. Sapardi Djoko Damono, dkk.).Jakarta: Pustaka Firdaus.Cet. II

A. Rivay Siregar. 2002 .Tasawuf: dari Sufisme Klasike ke Neo-Sufisme. Jakarta: PT RajaGrafindo Persada

----. 2004 .Tasawuf dari sufisme klasik ke neo sufisme. Jakarta: PT. RajaGrafindo Persada

Azyumardi Azra. 2004 .Jaringan Ulama Timur Tengah Dan Kepulanan Nusantara Abad Xvii \& Xviii; Akar Pembaruan Islam Di Indonesia. Jakarta: Prenada

Cecep Alba. 2012 .Tasawuf dan Thariqah, Dimensi Esoteris Ajaran Islam. Bandung: PT Remaja Rosdakarya

Dadang Kahmad. 2002. Thariqah dalam Islam: Spiritualitas Masyarakat Modern.Bandung: Pustaka Setia

Muhammad Fethullah Gülen. 2014 .Kalbin Zümrüt Tepeleri, Terj. Fuad Syaifudin Nur, Tasawuf Untuk Kita Semua. Jakarta: Anggota IKAPI DKI

Harun Nasution. 1990. Falsafat dan Mistisisme dalam Islam. Jakarta: Bulan Bintang.Cet. VII

----. 1978. Falsafat dan minisme dalam Islam. Jakarta: Bulan Bintang

Hawas Abdullah. tt. Perkembangan Ilmu Tasawnf dan Tokoh-tokohnya di Nusantara.Surabaya: al-Ikhlas

Ibn Saad. 1997. Purnama Madinab: 600 Shababat Wanita Rasulullab SAW yang

Menyemarakekan Kota Nabi (terj. Eva Y. Nukman).Bandung: al-Bayan 
Perempuan dalam Thariqah (Studi Terhadap Peran Perempuan Dalam Thariqah Tijaniyah Bangka)

Irwan Abdullah. 2002. "Metode Penelitian Kualitatif: Suatu Pengantar Umum”, Materi Pelatihan Fakultas Psikologi Universitas Muhammadiyah Surakarta

Jajat Burhanudin (ed.). 2002.Ulama Perempuan. Jakarta: Gramedia Pustaka Utama

Javad Nurbakhsh. 1996.Wanita-wanita Sufi(terj. M.S. Nasrullah dan Ahsin Muhammad).Bandung: Mizan

Margaret Smith. 1997.Rabi'ab: Pergulatan Spiritual Perempuan (terj. Jamilah Baraja). Surabaya: Risalah Gusti

Martin van Bruinessen. 1998 .Thariqah Naqsabandiyah di Indonesia. Bandung: Mizan.Cet. $\mathrm{V}$

Marzuki Wahid, dkk. (ed.). 2007. Istiqro’ (Jurnal Penelitian Islam Indonesia) Vol. 06. No. 01

Muhammad Solikhin. 2009. Tradisi Sufi Dari Nabi. Yogyakarta: Cakrawala

Muhammad Fethullah Gülen. 2014. Kalbin Zümrüt Tepeleri Terj. Fuad Syaifudin Nur, Tasawuf Untuk Kita Semua. Jakarta: Anggota IKAPI DKI

Moh. Saifulloh Al aziz Senali. 2000. Tashawuf Dan jalan Hidup para Wali. Gresik: Putra Pelajar

Mustafa Zahri. 1976. Kunci memahami Ilmu Tasawnf. Surabaya: PT Bina ilmu

M. Solihin. 2001. Sejarah dan Pemikiran Tasawuf di Indonesia. Bandung: Pustaka Setia

Ris'an Rusli. 2013. Tasawuf dan Thariqah. Jakarta: Rajawali Pers

Robert K. Yin. 2005. Studi Kasus: Desain \& Metode(terj. M. Djauzi Mudzakir). Jakarta: RajaGrafindo Persada

Rosihon Anwar. 2010. Akblak Tasawnf. Bandung: Pustaka Setia

Saiful Mujani. 2007. Muslim Demokrat: Islam, Budaya Demokrasi, dan Partisipasi Politik di Indonesia Pasca-Orde Baru. Jakarta: Gramedia Pustaka Utama

Sanapiah Faisal. 1999. Format-format Penelitian Sosial.Jakarta: RajaGrafindo Persada. cet. IV

Simuh. 2002. Tasawuf dan Perkembangannya dalam Islam.Jakarta: Rajawali Press.Cet. II

Sri Mulyati. 2006. Thariqah-Thariqah Muktabarah Di Indonesia. Jakarta: Kencana Prenada Media Group

Syam'un Ni'am. 2001. Cinta Ilabi Perspektif Rabi'ab al-Adawiyah dan Jalaluddin Rumi. Surabaya: Risalah Gusti

Syeikh Fadhlullah Haeri. 1998. Belajar Mudah Tasawuf. Jakarta: Lentera Basritama

Syekh 'Ustman al-Kharbani. 2008. Kisah Cinta Rabiah al-Adawiyah (terj. A. Bahruddin Sholihin).Jogjakarta: Diva Press.Cet. VI

Tim Penyusun. 2010. Islam dan Isu-isu Kontemporer: Artikel Dakwah dari Jurnal dan Website. Jakarta: Ditjen Bimas Islam Kemenag RI

Zamakhsyari Dhofier. 1990. Tradisi Pesantren.Jakarta: LP3ES

----. 2011. Tradsis Pesantren. Jakarta: LP3ES

Zulkifli. 2007. Kontinuitas Islam Tradisional di Bangka. Sungailiat: Shiddiq Press. 